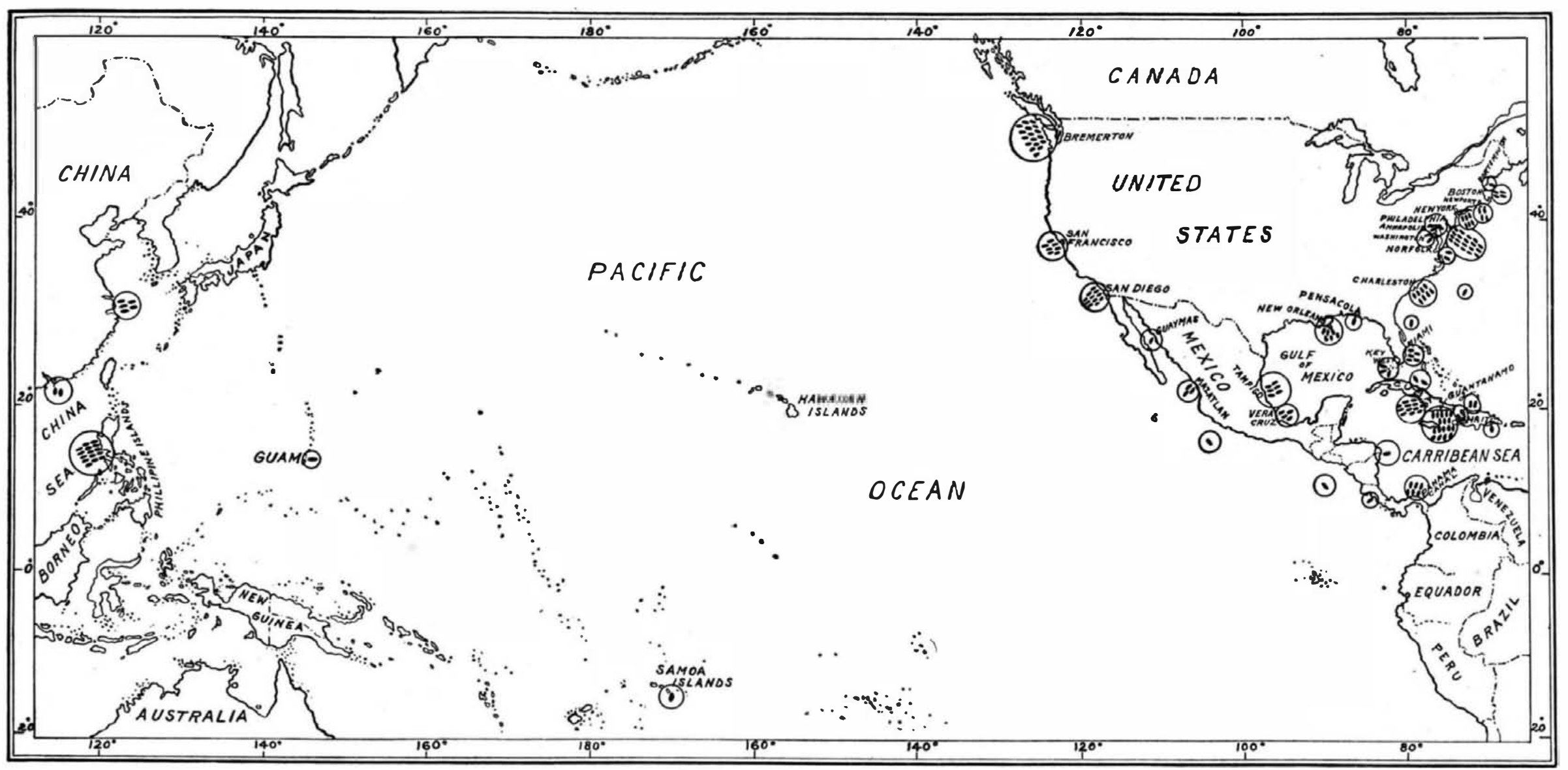

Map showing disposition of ships of the United States Navy on February 12th, 1914.'

\title{
The Problem of Our Navy
}

\section{I.-How the Navy is Daily Employed}

\section{By Hon. Franklin D. Roosevelt, Assistant Secretary of the Navy}

A CERTain person of some prominence in public A life, who should have known better, recently referred to the American Navy as an organization of "highly paid idleness."

In regard to the pay of the Navy, it is sufficient to dismiss the allegation with the statement that the a verage pay of all the officers and enlisted men in the service amounts to just $\$ 618$ per annum apiece. But the use of the word "idleness" leads me to fear that there must be some people who are not familiar with the manner of occupation of the ships and men of the service in times of peace.

In my office in Washington hangs a map of the world, showing by means of pins the location each day of the ships of the Navy. This map is a constant source of interest and surprise to visitors, and any study of it leads to the inevitable conclusion that our vessels and the men who man them lead an existence of constant occupation and useful effort, that is surpassed by no other agency of the Government of the United States.

no other agency of the Government of the United States. It so happened that on the 12th of February, 1914,
all the ships of the Navy, with the exception of a small gunboat used as a station ship at Constantinople, were located between the longitude of Santo Domingo on the east and that of Canton on the west. Therefore the appended map includes only that portion of the earth's owever, that only a few months ago we had battleships in the Mediterranean, cruisers in South American waters and in other places not shown on this map, and that it represent only the locations shown on the Department map on the day it happened to be copied for reproduction in the Scientific American. Every day of the year the pins are changed as the ships move on their never-ending duties.

Some of their occupations are self evident; but a short explanation of why each ship is in each particular place will perhaps in itself give a better answer to the question, "Why have we a navy?" than would a dozen long volumes on sea power or strategy. For the accompanying map shows both the strength and the weakness, the sufficiency and the crying needs of the American Navy to-day.

Starting with the Asiatic fieet, there are shown five light draught river gunboats on the Yangtse River in China and two near Canton, all of them used on friendly patrol duty which has been going on for man decades.

To the southward concentrated in the Philippine Islands is the main body of the Asiatic squadron, consisting of the following vessels : Cruisers "Saratoga," "Cincinnati," "Galveston;" monitors "Monterey, "Monad nock ;" 1 gunboat; 5 torpedo boat destroyers; 0 submarines; 4 auxiliaries-a total of 21 vessels which in time of peace is sufticient to guard the various American in-
Modern naval wars start with all the surprise and destructive shock of an explosion of dynamite, as witness the Japanese destroyer attack which so seriously crippled the Russian fleet at Port Arthur before any declaration of war had been made. Modern naval wars are won when the battleship fleets meet and fight it out to a finish on the high seas; as happened later when Japan annihilated the Russian first line of battle at Tsushima. The navy of a great nation like the United States must be proportioned to the magni ture of that nation's international policies-to the distance from home and the area of the field in which it may be engaged in hostilities-and above all, to the size and strength of the first battleship line of those nations which may dispute by armed force that nation's policies. As matters now stand, the United States is endeavoring to support firstclass policies with a third-class navy. Measured by the daring of our policies and the boldness with which they are being proclaimed, our fighting line of dreadnoughts is about one half as powerful as it should be. The navy, as it stands to-day, is short of men, short of torpedoes, has no comprehensive scheme of swift mobilization-has, in fact, no adequate reserve of men with which to mobilize; and in case of sudden complications with a foreign power over, say, the Monroe Doctrine or the Panama Canal, would find itself incapable of entering into a uar with any hope of that quick success, which will be achieved by the nation that engages with a preponderance of dreadnought strength and the ability to mobilize its whole fleet in a week or ten days' time.

These are some of the questions which we shall consider in the series of articles on "The Problem of Our Navy," of which this is the first.

But the Navy, though deficient in quantity-in ships, officers and men-is absolutely first class in quality. That the nation is being well served, day by day, in these times of peace, is shown in the following very able article by the Assistant secretary of the Navy.-EDitor.

terests in the island and other parts of the Far East, but which in time of war against any important naval power would be practically a negligible quantity. For it goes without saying that cruisers, old monitors, and a few destroyers and submarines could not long withstand an attack by a moder tenance of these ships of small fighting value in the Far East is justified not as a war measure, but because American activities, not only in our own possessions but in all the neighboring seas and countries, require in time of peace the moral support of the ships' presence Moving eastward on the map our next vessel is seen at the island of Guam, serving as a station ship for the island government, which is conducted with conspicuous success by a naval officer. In fact, a comparison of conditions on that out of the way speck in the Pacific with those existing before American occupation, or even with those existing to-day in nearby islands under the rule of another power, shows a real accomplishment of which the Navy and the American people can be proud. The same statement can be made about our other Navy-governed possession of Tutuila, or American Samoa. Here also a gunboat is maintained as a station ship.

Turning now to the northern Pacific, it will be seen that no ships are stationed at Hawaii. This is, how ever, only a temporary condition, and the completion of the Pearl Harbor Naval Station will make this an important strategic base.

In Puget Sound is located the Pacific Reserve Fleet consisting of the following ships: battleship, second line, "Oregon;" armored cruisers "South Dakota," "West Virginia," "Colorado;" cruisers "Albany," "Charleston," "Chattanooga," "St. Louis," "Milwaukee;" 2 submarines; 5 auxiliaries. These ships are maintained with skeleton crews, and while still serviceable in battle against enemies' ships of equal age, would have small military value against a more modern fieet. In addition to these, a submarine recently completed is being placed in commission at Puget Sound.

In San Francisco Bay are the cruisers "Cleveland" and "Marblehead" (in reserve); 1 gunboat; 4 submarines; 4 torpedo boat destroyers (in reserve) ; 2 torpedo boats (in reserve); 2 auxiliaries. It may here be noted that the necessity for the presence of ships in Mexican waters and for other important duties makes it highly undesirable to keep so many ships on the Pacific Coast in reserve, but the lack of sufficient officers and men to place them in full commission makes any other course impossible; and this in spite of the fact that the quota of men allowed is at present up to the legal limit.

Near Santa Barbara and San Diego, California, 5 torpedo boat destroyers with a parent ship are engaged in their annual maneuvers and torpedo exercises. Two submarines with an attendant monitor are also engaged in their practice drills in this vicinity, and the armored cruisers "Maryland" and "California" are holding their usual winter target practice. All of this work corresponds to the drills of the Atlantic fleet in West Indian waters each winter, but the shortage of men and the unusual international requirements have of late prevented the carrying out of these exercises in the manner the Department would like to see. 
Farther south on the west coast of Mexico are found the armored cruiser "Pittsburgh," cruisers "Raleigh" reasons for their presence in these waters require no comment.

Still farther south the cruiser "Denver" is proceed ing to relieve the transport "Buffalo" at Corinto, Nicaragua, where for some time the State Department has considered the presence of an American warship desirable. This completes the list of ships in the Pacific Ocean. They seem formidable in numbers, and they are doing valuable work of almost every conceivable kind, but as a fighting force against a modern fieet they must not be h ighly estimated.

In the Atlantic Ocean is found both the greatest numerical and the chief military strength of the Navy. Far to the north in the Gulf of St. Lawrence, but not shown on the map, the naval tug "Potomac," bound on an errand of mercy to rescue the crews of American fishing boats, has herself been caught in the icefioes and at this writing is in grave danger of destruction. At Portsmouth, N. H., the cruiser "Tacoma" is undergoing repairs. At Boston the second line battleship "New Jersey," recently from Mexico, is being overhauled; the armored cruiser "North Carolina" and the cruiser "Chicago" are in reserve, and a new submarine is being placed in commission. At Newport 4 old torpedo boats are maintained in reserve and a submarine is being fitted out.

At New York the first line battleship "North Dakota" is repairing; the first line battleship "Arkansas" is in quarantine with a few cases of illness on board; the armored cruiser "Washington" is used as a receiving ship; a gunboat is in reserve, and a monitor and submarine are preparing for the formation of a new submarine division.

At the Philadelphia Navy Yard are the cruise "Montgomery," 2 destroyers in reserve, and a submarine fitting out; and here also are stationed the ships of the Atlantic Reserve Fleet, as follows: Second line battleships "Idaho," "Maine," "Missouri," "Alabama," "Illinois," "Kearsarge," "Kentucky," "Wisconsin," "Indiana," "Iowa," "Massachusetts;" the armored cruiser "Tennessee," the cruiser "Salem" and repair ship "Panther." As in the case of other ships in reserve, they are from the military point of view valuable for fighting purposes only against ships of an equal or greater age. That it would amount to little less than murder to send American officers and men out in these old ships to fight against a fieet of modern dreadnoughts is a simple truth that everyone should understand. These ships have still a possible use; but to place reliance on them in a time of crisis could never be warranted.

At the Naval Academy at Annapolis are stationed 5 torpedo boats, and at Washington two converted yachts, In the Norfolk Navy Yard the second line battleship "Vermont" is undergoing repairs to the shaft broken while returning from the Mediterranean, and the monitor "Tallahassee" is being used for ordnance experiments. Off Cape Hatteras the first line battleship "Michigan" is proceeding south to join the other ships of the second division at Guantanamo.

Charleston, S. C., is the regular base of the torpedo boats and destroyers in reserve, but only 5 of the forme and 3 of the latter, together with 1 submarine, are there at the present time. The rest of the reserve destroyers, 6 in all, are on the coast of Florida engaged in their annual practice cruise for a period of two months. These vessels are manned by only half crews, but are kept on the whole in an efficient condition and are not obsolete. At Key West three new destroyers recently placed in commission are engaged in "shaking down" trials and in torpedo practice preliminary to takin their places with the Atlantic fieet. In Pensacola Bay the second line battleship "Mississippi" is being used in experimental aeronautic work. At New Orleans the monitor "Tonapah" and the second submarine group of 5 vessels are engaged on the annual practice cruise. Off the north coast of Cuba the "Prairie" and "Hancock," transports, are returning with two regiment of marines from a month of "advance base" maneuver on the island of Culebra, just east of Porto Rico. Thi work consists, as the name implies, in landing and fortification drills with the object of establishing a base on a hostile shore.

South of Cuba all the ships of the Atlantic fleet, except those in Mexican and Haitian waters, are engage in the regular winter practice work-fleet and division drills, torpedo and target practice, boat drills, etc. At Guantanamo Bay are the following ships: Second line battleships "Louisiana," "Kansas," "New Hampshire;" cruiser "Birmingham," 1 gunboat and 12 torpedo boat destroyers

A little farther to the west, near Guacanaybo Bay, Cuba, are the rest of the ships of the Atlantic fleet, engaged in similar practice: First line battleships boat destroyers, and one destroyer tender.

The island of Haiti has recently required the almost constant presence of one or more American ships. At coast of Haiti are the battleship "South Caroling," the and "San Francisco," and the surveying ship "Eagle." The "Montana" was engaged in torpedo training exercises and the "San Francisco" in mine laying practice off the Cuban coast, but both were hurried to Haiti on the outbreak of the revolution there.

On the east coast of Mexico, performing an obvious duty, are the following ships: At Tampico: Second line battleships "Rhode Island," "Georgia," "Nebraska," "Virginia ;" cruiser "Des Moines;" and 1 gunboat. At Vera Cruz: Second line battleships "Connecticut," "Ohio," "Minnesota," and cruiser "Chester." Off the coast of Honduras the auxiliary "Hannibal" is engage in hydrographic surveying. Finally, at Cristobal, the Atlantic end of the Panama Canal, are 5 submarines and their "mother" ship the gunboat "Severn"

I regret that it is impossible in this short article to describe in detail the daily life of the officers and me on board all these ships in both oceans. Ask any of them and they will tell you that there are few moments for idleness, that the many duties require constan mental alertness and physical fitness, and that the man who wants to succeed has in the service to-day a field of opportunity greater than ever before.

Such was the disposition of the American Navy on the 12th day of February, 1914. Briefly, it shows that in times of peace it is as an organization very muc occupied with many different kinds of work in many different places; that it is keeping the peace, preventing bloodshed and disorder, governing islands, carrying on scientific work for the benefit of commerce, seeking to rescue castaways, and doing daily a hundred unsung deeds that make it an American institution to be proud of.

But there are other facts to be deduced also-facts based on the premise that the primary object of the Navy is to be ready in the unfortunate event of war. To this end all others must of necessity be subordin ated. Just as the police force of a city is of little value in stopping the invasion of a country by a foreign force, so the work of the gunboats and surveying ship and obsolete battleships in time of peace would count for little against the enemy's fleet in time of war. The day is past when it was possible to build, equip and man a frigate in six months. Now a battleship which takes three years to build cannot be taken into an engagement by any kind of officers or any kind of a crew. Many months of thinking, toil and practice are necessary to efficient maneuvering and straight, quick shooting.

A naval war of to-day would not see single ships in action, nor would it see a fleet divided and scattered along the two coasts of the continental United States. A glance at the map shows a part of our activities and interests outside of this continental portion in time of peace. Would we then in time of war be content like the turtle to withdraw into our own shell and see an enemy supersede us in every outlying part, usurp our commerce and destroy our infiuence as a nation throughout the world?

Yet this will happen just as surely as we can be sure of anything human, if an enemy of the United States obtains control of the seas. And that control is dependent absolutely on one thing-the preponderant efficiency of the battle fleet. A thousand gunboats, a thousand harbor-defense submarines or monitors would avail us nothing. Invasion is not what this country has to fear. If the American people are willing to be relegated to the position of a nation unimportant in the reat affairs of the world, without influence in commerce, or in the extension of peaceful civilization and high ideals throughout the world, they need no battleships, they need not fear the loss of control of the seas. Students of naval warfare, naval officers, historians, are as a whole as desirous of peace as any class of Americans; they deplore the struggle of the nations to guard themselves with military preparations, but they realize that we are confronted with a fact and not a theory. The day will come, they hope, when armaments will be limited by international agreement, and they are ready to help hasten that day. But until that day is an assured fact the American Navy must keep the principles of a possible naval conflict always in mind. The efforts of all must be concentrated, as far as possible, on the preparation of the battle fleet. That fleet must at all costs be kept together, for division of forces is fatal; it must be drilled and maneuvered; it must spend good money for target practice; it must contain the best material and the latest devices; and it must in its personnel typify the highest ideals, the greatest efficiency of American citizenship.

\section{Sir David Gill}

$S_{\text {IR DAVID GILL, the eminent astronomer, died in }}$ his age. He was educated at the University of Aberdeen, and spent the time between his twenty-fffth and

thirtieth years in preparing himself to be an astronomer at a private observatory in Aberdeen. During the next three years, 1873 to 1876 , he directed the private observatory of the late Earl of Crawford, then Lord Lindsay, and organized the Lord Lindsay expedition to Mauritius to observe the transit of Venus; the obserations being undertaken with a view to a redetermination of the distance of the sun, a problem which had a lasting interest for Sir David, and to which he was constantly returning.

From the measurement of the distance of the sun he turned to the measurement of the earth. During the same three years he connected the longitudes of Berlin, Malta, Alexandria, Suez, Aden, Seychelles, Mauritius, and Rodriguez, and measured the baseline for the geodetic survey of Egypt, near Cairo. This was the first step toward realizing what he called the dream of his life, namely, the measurement of the great African arc of the earth on the thirtieth meridian.

In 1880 he proposed the geodetic survey of Natal and Cape Colony, although the project was not carried to completion till sixteen years later. He lived to see the gap in the arc between Rhodesia and the Limpopo filled up and its subsequent extensions through German East Africa, along Lake Tanganyika, toward the Sudan. When that work is altogether completed the great arc will join that of Greece and Struve's great arc, which terminates at the North Cape, and will be the greatest length of the world's surface, 105 deg., more than 6,000 miles, to be measured with mathematical accuracy.

But before this, in 1877, he proposed and carried out an expedition to Ascension Island to determine the solar parallax by observations on Mars, and in 1879 he was offered the post of Astronomer Royal at the Cape of Good Hope. He continued his work along the lines of solar parallax determinations, organizing transit of Venus expeditions to this end.

In 1882 a great comet became visible, and Sir David, with the assistance of an intelligent Cape photographer, succeeded in obtaining some beautiful pictures of the comet, the camera being strapped on the telescope, and not only of the comet, but of the surrounding stars. They were the first really fine photographs of a comet, but they were also the first of the modern photographic star-plates, and from these photographs sprang the whole project of the great Star Map, which still engages the observatories of the world. From this also originated the new method of determining the sun's distance by photographic observations of the minor planet Eros. The spirit which inspired Sir David Gill in his work is best described in an extract from his presidential address to the British Association in 1907 :

"Accurate and minute measurement seems to the non-scientific imagination a less lofty and dignified work than the looking for something new. But nearly all the grandest discoveries of science have been the reward of accurate measurement and patient long-continued labor in the minute sifting of numerical results." $\mathrm{He}$ was the recipient of numerous honors, among others being the F. R. S. and K. C. B.

\section{International Map of the World}

THE second international conference on the "mil1 lionth" map of the world (Carte internationale du monde 1: 1,000,000) met in Paris, December 10th to 18 th, 1913, and was attended by representatives of thirty-four countries. Although the fundamenta features of this chart were settled at the original conference, in London, many special problems have arisen, and these the second conference attempted to solve Specimen sheets of the chart have already been prepared by Great Britain, France, Spain, Italy, the United States, Japan, Mozambique, and Sweden. At the London meeting it was decided to include on the chart place-names in common international use in addition to the official names used in the several countries. The Hungarian delegation at Paris endeavored unsuc cessfully to have all but the official names eliminated. In the discussion on this subject Prof. Partsch pointed out that the world at large would hardly recognize Jerusalem and Damascus under their official names of El-Kuds and Esh-Shâm, respectively. An additional argument in favor of retaining customary intemational names is that official names are subject to change with changes of sovereignty (as, for example, after the recent war in the Balkans). It was decided to establish permanent headquarters for the undertaking at London and Southampton. The next conference will be held in Berlin toward the end of the present year.

The "Limequat."-This portmanteau name has "Les a new hybid, obtained by crossing the West Indian lime with the kumquat. The tree is much hardier than the lime, having withstood the past thre winters in extreme northern Florida, where the lime 